\title{
Glacier Forelands - Unique Field Laboratories for the Study of Primary Succession of Plants
}

\author{
Thomas Fickert \\ Additional information is available at the end of the chapter
}

http://dx.doi.org/10.5772/intechopen.69479

\begin{abstract}
While receding glaciers in several respects are related to negative consequences for resident people down river (e.g., water security, glacial lake outburst floods, etc.), from an ecological point of view, they are unique field laboratories to study vegetation development and dynamics from the very beginning. As the bare ground exposed by the receding glaciers generally does not provide a seed bank, the colonization of formerly ice-covered ground represents a true primary succession. There are two different approaches to study vegetation dynamics in glacier forelands: permanent plots and chronosequences ("space for time substitution"). As both procedures have their respective pros and cons, they should not be regarded to be mutually exclusive; rather, they should complement each other for a comprehensive understanding of the vegetation dynamics in glacier forelands. This chapter gives a general overview on patterns and processes of vegetation development in glacier forelands based on vegetation sampling in two glacier forelands of the Eastern Alps employing both abovementioned approaches. Sampling records groundcover of all vascular plants, structural features such as life form composition and dispersal biology types of the species as well as site characteristics. The two different approaches give evidence for both the early vegetation dynamics after deglaciation by the permanent plot studies and for potential future developments by the chronosequences.
\end{abstract}

Keywords: receding glaciers, vegetation dynamics, plant colonization, permanent plots, chronosequences

\section{Introduction}

The renowned German ecologist Heinz Ellenberg made a good point when stating "Nowhere can succession be studied more profitably than in the valley below the front of a large glacier" [1]. The opportunity to directly observe the vegetation development on 
new, hitherto unvegetated ground has fascinated botanists ever since, and in the European Alps, studies on vegetation development in glacier forelands date back well into the midnineteenth century. There are two fundamentally different approaches to study vegetation dynamics in glacier forelands: permanent plots and chronosequences ("space for time substitution" sensu [2], see Figure 1). Due to time constraints, the latter method is commonly employed, using spatially different sites to reconstruct a temporal sequence. In glacier forelands, dateable traces of the earlier extent of glaciers are commonly used [3], sometimes combined with lichenometric dating [4]. While the chronosequence approach is suitable to document shifts in species composition and vegetation structure as response to the time since melt-out, it does not give evidence how the colonization of bare ground is actually taking place. In addition, as different sites may be influenced by varying site histories, by unsimilar effects of the surrounding and/or topography (exposure, slope angle, etc.) or by differences in the frequencies and/or magnitudes of disturbances, not only the time since melt-out might be essential for the vegetation development observed.

A very accurate appraisal of the colonization dynamics in glacier forelands can be obtained by permanent plots. If an adequate number of resurveys is provided, permanent plot studies give good evidence on migration patterns, shifts in frequency or abundance of species, growth performance, and temporary setbacks. In addition, they allow to identify whether the development of species numbers or ground cover follows a more linear or more logarithmic trend and whether a trend reversal due to inter- and intraspecific competition at any point during succession occurs (see Figure 2). The downside of permanent plots is that a high level of patience is needed, a rare virtue in this day and age. Thus, it is no surprise that only few long-running permanent plot studies on primary succession in glacier forelands of the Alps (and beyond) exist.

As both procedures have their respective pros and cons, they should not be regarded to be mutually exclusive; rather, they should complement each other for a comprehensive treatment of the vegetation dynamics in glacier forelands. While the permanent plot studies give evidence for the early colonization by plants of the bare ground exposed by the receding glaciers, the chronosequences give hints for the long-term vegetation dynamics within glacier forelands. The own results presented here will be put into a larger context to give a general overview on patterns and processes of vegetation development in glacier forelands of the Alps. The following topics are of particular interest:

- How fast is the colonization of the bare ground taking place? Several studies showed that high-elevation plant species despite favorable dispersal modes (predominantly lightweight wind-dispersed seeds) show delayed vegetation dynamics due to high mortality rates during establishment (e.g., Refs. [5, 6]).

- Does colonization of the bare ground provided by receding glaciers follow a more linear or a more logarithmic trend (positive, i.e., delayed at the beginning, accelerated later on; negative, i.e., vice versa; see Figure 2)?

- Is there a point of trend reversal (e.g., decreasing species and/or individual numbers) due to increasing interspecific and intraspecific competition during succession (Figure 2)? 
- How do site conditions (elevation, exposure, substrate, snow cover duration, microclimatic conditions, etc.) affect vegetation dynamics?

- Do facilitating or inhibiting interactions between species exist, and if so, at what moment do these become apparent [7-11]?

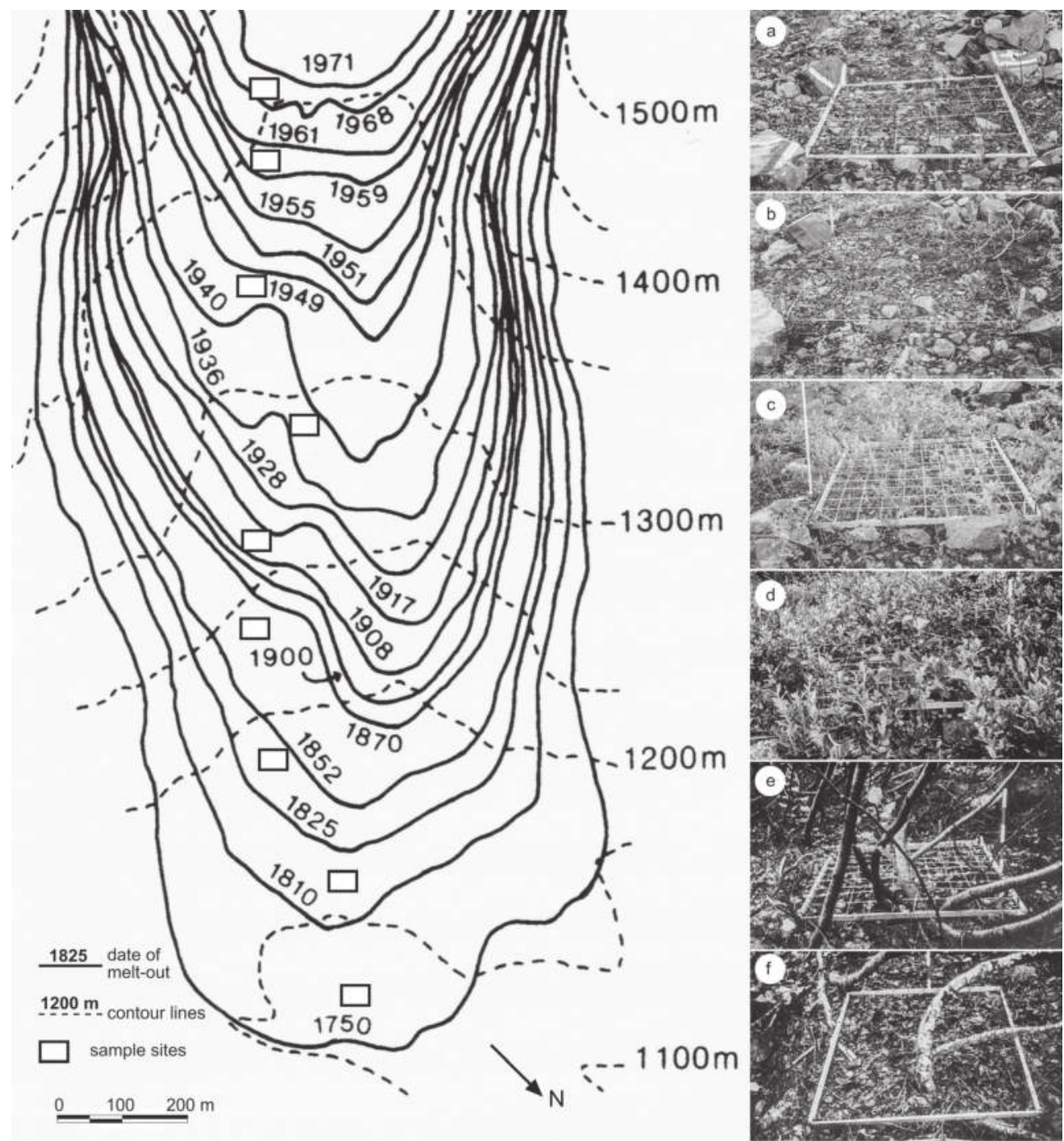

Figure 1. Juxtaposition of the two general procedures for studying succession of plants in glacier forelands: chronosequences using spatially different sites to reconstruct a temporal sequence (left, shown is Storbreen glacier in Norway) and permanent plots observing vegetation development on one and the same sample site (right, shown is Coopers Quadrat \#1 at Grand Pacific Glacier, Alaska; $a=1921, b=1935, c=1949, d=1955$, e = 1967, f = 1982) (modified from Refs. $[3,17])$. 


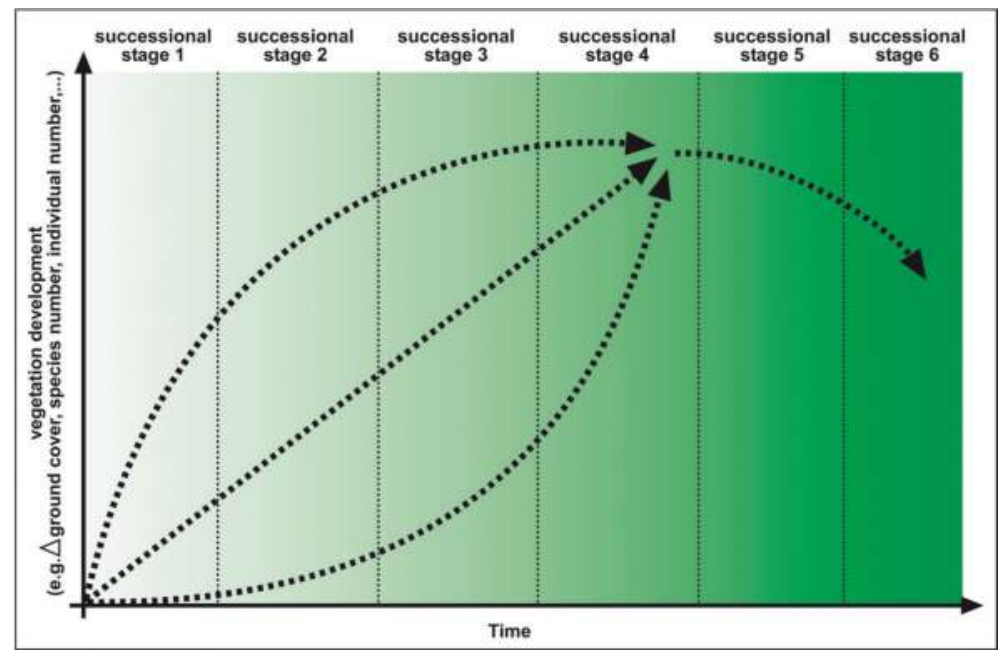

Figure 2. Hypothetical successional trajectories carrying linear or both positive and negative logarithmic/exponential characters. At a particular stage also reverse trends of decreasing species or individual numbers might occur.

\section{Study sites, sampling design, and analyses}

The two glacier forelands studied are located in the Central Eastern Alps. In summer 2005, permanent plots were established immediately in front of Goldbergkees (Hohe Tauern, Austria) and Lenksteinferner (Rieserferner, Italy), which were revisited every second year thereafter. In 2010, chronosequences were established within the same glacier forelands extending from the permanent plots down to moraines of the Little Ice Age (LIA) maximum which occurred around 1850. Table 1 summarizes basic information on both study areas.

Sample sites are $10 \mathrm{~m}^{2}(2 \times 5 \mathrm{~m})$ for both the permanent plot and the chronosequence studies and represent "mean" site conditions (i.e., no hollows with above-average snow cover duration or wind-exposed knolls with drier conditions). The permanent plots are arranged in two different sets. The A-sites were installed close to the glacier terminus (2-8 $\mathrm{m}$ in front of the ice margin in 2005), the B-sites 7-12 m away from the A-sites. Most sites became deglaciated in the year of the initial survey, and some of the B-sites probably already the year before. In total, 26 sample sites at Goldbergkees (13 A, 13 B) and 22 at Lenksteinferner (11 A, 11 B) are studied. Sites are GPS-recorded, flagged, and photo-documented for a precise match at resurveys. Vegetation sampling records groundcover and individual numbers of all vascular plants as well as structural features such as life form composition [12] and dispersal biology types [13] of the species. Mosses are sampled as undifferentiated species group. Taxonomy of vascular plant species follows [14]. Sampling occurs $\mathrm{m}^{2}$-wise with the smallest unit being $0.01 \%$ ground cover (i.e., $1 \mathrm{~cm} \times 1 \mathrm{~cm}$ on a $1 \mathrm{~m}^{2}$ subplot). Raw data are subsequently converted to mean ground cover values as well as total number of species and individuals per $10 \mathrm{~m}^{2}$ sample site. 


\begin{tabular}{lll}
\hline & Goldbergkees & Lenksteinferner \\
\hline Geology & Granitoid rocks & Granitoid rocks \\
Number of permanent plot samples & $13 \mathrm{~A}, 13 \mathrm{~B}$ & $11 \mathrm{~A}, 13 \mathrm{~B}$ \\
Elevation permanent plots & $2390-2420 \mathrm{~m}$ a.s.l. & $2600-2630 \mathrm{~m}$ a.s.l. \\
Elevation LIA terminal moraine & $2180 \mathrm{~m}$ a.s.l. & $2340 \mathrm{~m}$ a.s.l. \\
$\begin{array}{l}\text { Number of chronosequence stages } \\
\text { (three samples each) }\end{array}$ & 8 & 9 \\
Horizontal extent chronosequence & $1300 \mathrm{~m}$ & $1250 \mathrm{~m}$ \\
Vertical extent chronosequence & $200 \mathrm{~m}$ & $280 \mathrm{~m}$ \\
\hline
\end{tabular}

Table 1. Basic data on the permanent plot and chronosequence studies within the glacier forelands of Goldbergkees and Lenksteinferner.

The chronosequences extend from the permanent plots down to the LIA terminal moraines. For both glacier forelands detailed chronologies about glacier retreat since LIA maximum exists $[15,16]$, allowing for a quite accurate age determination of sample sites. At Goldbergkees, the total horizontal distance between the youngest and oldest sites is $1.3 \mathrm{~km}$ and $200 \mathrm{~m}$ elevational difference, on Lenksteinferner $1.25 \mathrm{~km}$ and $280 \mathrm{~m}$, respectively. On Goldbergkees, eight different stages of time since melt-out were studied ( 2 years, 4 years, 15 years, 25-30 years, 55 years, 85 years, 120 years, 155 years) and on Lenksteinferner, nine different stages ( 2 years, 4 years, 20 years, 35 years, 55 years, 75 years, 90 years, 120 years, 155 years). Each stage is represented by three $10 \mathrm{~m}^{2}$ plots. For the youngest stages ( $<10$ year-ice-free), three of the permanent plot samples were used (three A-sites of 2007, three B-sites of 2009). Vegetation sampling is primarily the same as on the permanent plots, with the only modification that individual numbers are not counted. Environmental variables collected in situ for all sample sites of both approaches are elevation (by altimeter), exposure (by compass), slope angle (by clinometer), and rockiness of the ground (by visual estimation of coarse rocks $>6 \mathrm{~cm}$ in \%).

For data analyses, univariate and multivariate statistical procedures were employed. To assess the successional development in glacier forelands quantitatively, documented changes between different samples are crucial - temporally different in the case of the permanent plots and spatially different in the case of the chronosequences. Primary succession in glacier forelands commonly starts with simple agglomerations of plants and subsequently becomes more and more complex. The increasing complexity during succession becomes obvious in change measures such as mean ground cover values (of singular species and total) as well as species and individual numbers. Temporal trends are derived by linear and/or nonlinear regressions. The range of variation in data sets (species numbers, individual numbers, groundcover, etc.) is depicted by box and whisker plots.

For detecting gradual changes in species composition within large data sets, ordination procedures assuming underlying gradients within data sets are appropriate tools. By means of similarity relationships, gradual changes of samples concerning species composition are calculated in a multidimensional ordination space. The aim of ordinations is to reduce the 
number of dimensions and to make complex datasets with many species and samples interpretable. For the chronosequence data, unconstrained linear principal component analyses (PCAs) are employed. The graphic presentation of ordination analyses is by two-dimensional scatter plots displaying samples and/or species; explanatory environmental variables (if available) are displayed as arrows. The arrows point from the origin of ordinates in the direction of samples with above average values of the particular variable; the length represents the relevance of the variable. Gradient analyses were performed with Canoco 4.5.

\section{Early plant colonization in glacier forelands as revealed by permanent plot studies}

After glacier retreat, new ground is provided for plant colonization. Substrate of the sample sites is variably rocky with amounts of rocks $>6 \mathrm{~cm}$ between less than $25 \%$ to well over $80 \%$. Figure 3 portrays the early vegetation development in the glacier forelands of Goldbergkees and Lenksteinferner, showing basically similar trends concerning species numbers, individual numbers, ground cover, and life form composition.

At the initial survey in 2005, the A-sites immediately in front of the ice margin were entirely free of plants in both glacier forelands, while on the B-sites, a couple of species with very few individuals were already present. The early colonizers are the chamaephytes Arabis alpina, Cerastium uniflorum, Saxifraga bryoides, and Saxifraga oppositifolia; the herbs Oxyria digyna and Veronica alpina; as well as the grass Poa alpina on Goldbergkees and A. alpina, Cerastium cerastoides, C. uniflorum, the stoloniferous herb Geum reptans, and the grass Poa laxa on Lenksteinferner (Figure 4; for complete species lists of the two permanent plot studies, see Ref. [17]). Two years later also on the A-sites, the first individuals appear. On B-sites species and individual numbers exponentially increased, while ground cover is still low (Figure 3). The increasing trend continues during the first decade, slowing down slightly for species and individual numbers but accelerating for ground cover (Figure 3). In 2015, a total of more than 30 species are present on the permanent plots on Goldbergkees (median of individual A- and B-sites is 13 and 15, respectively) with over 1000 and 2000 individuals on the A- and B-sites, respectively. Somewhat lower are the values for the sample sites on Lenksteinferner with 22 species on the A-sites and 30 species on the B-sites (median of individual A- and B-sites is 8 and 11, respectively), with about half of the individual numbers of Goldbergkees $(>500$ on A-sites, just under 900 on B-sites).

Besides differences in absolute values concerning species numbers, individual numbers, and ground coverage (Figure 3), the permanent plot studies in the glacier forelands of Goldbergkees und Lenksteinferner prove a swift colonization of the bare ground and reveal generally similar trends in vegetation development. Vegetation dynamics in glacier forelands are controlled by three fundamental steps; all of them "may have, perhaps, the power to be the important limiting factor for succession and ecosystem development" [18]: step 1 is reaching the bare ground, step 2 is a successful establishment, and step 3 is growth and spreading. 


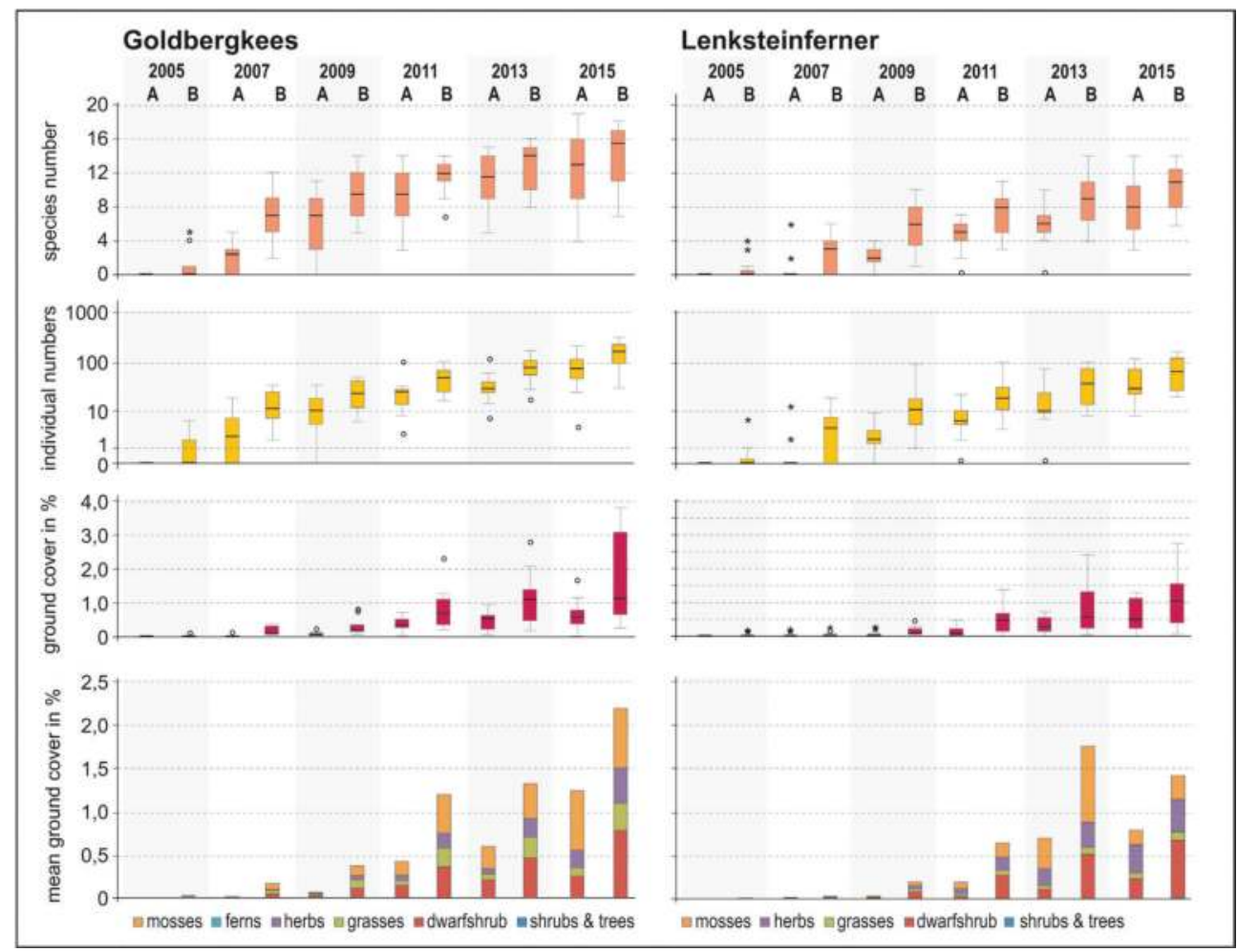

Figure 3. Vegetation dynamics on permanent plots (A- and B-sites) in the glacier forelands of Goldbergkees (left) and Lenksteinferner (right) between 2005 and 2015. Development and variation between sites are shown by box and whisker plots for species numbers, individual numbers, and ground cover (for vascular plants only); at the bottom bar plots show mean life form spectra.

\subsection{Step 1 in primary succession: getting there}

Reaching the bare ground is the first obstacle organisms have to conquer when colonizing new terrain. For this task, both a diaspore supply in the surroundings and the ability of a species to disperse from the seed source to the new ground are crucial. Concerning the former aspect, it makes a difference whether a glacier terminates within closed (sub)alpine vegetation with a rich diaspore supply or within sparsely vegetated scree slopes of the subnival belt. Several studies [19-22] have shown that recently deglaciated glacier forelands within the subalpine and lower alpine belt are colonized more quickly and more diverse concerning species numbers and life form composition than smaller glaciers terminating within the species poor upper alpine and subnival belts [1]. In addition, the few species present at higher elevations of the Alps do-despite small diaspores - not always possess high dispersal ability $[5,11]$, thus further impeding colonization. Seeding experiments, at least, have shown that artificial seed supply enhanced vegetation dynamics in glacier forelands and - what is even more important - that plant species are able to establish, which would hardly reach the bare 

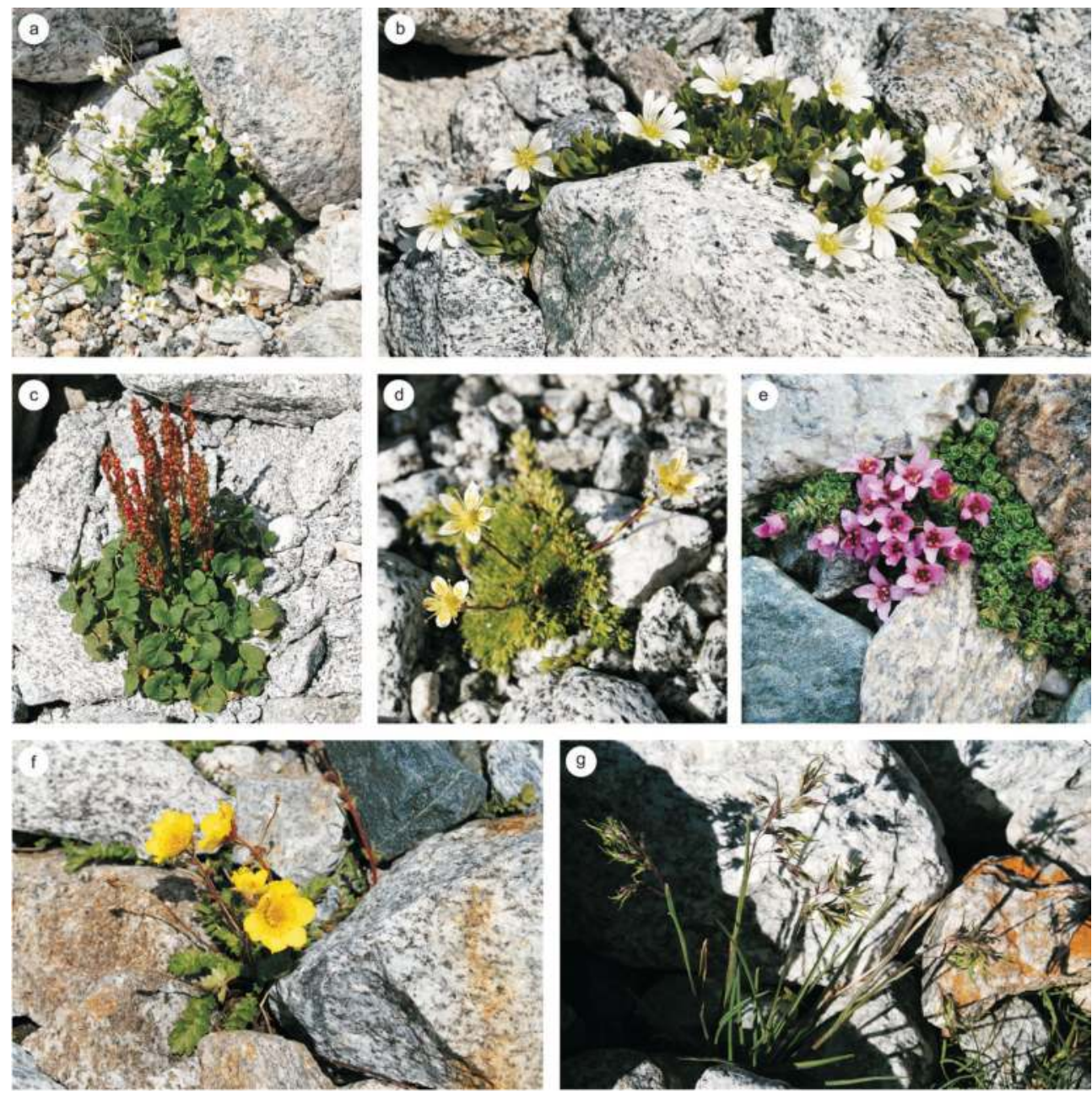

Figure 4. Characteristic early colonizers of central Alpine glacier forelands: Arabis alpina (a), Cerastium uniflorum (b), Oxyria digyna (c), Saxifraga bryoides (d), Saxifraga oppositifolia (e), stoloniferous Geum reptans (f), and Poa alpina (g) in the bulbil-producing ("viviparous") form.

ground by natural dispersal vectors [5, 11]. Nevertheless, commonly it does not take long until the first plant species in recently deglaciated high alpine glacier forelands (i.e., $>2200 \mathrm{~m}$ a.s.1.) appear. Time frames reported range between 1 and 8 years [1,21-24], and also the own survey attests a swift colonization with the first individuals appearing within 1-2 years [17]. The first colonizers are anemochorous taxa throughout, carried to the glacier foreland by valley winds from the surroundings and from lower elevations, too [25-27]. Thus, early colonizers are not only pioneer species sensu stricto (i.e., early colonizers not able to persist over time during succession, e.g., S. oppositifolia, Saxifraga exarata) but also early- to late-successional 
taxa (i.e., those that persist over time during succession but are able for early colonization as well, e.g., A. alpina, C. uniflorum, O. digyna, S. bryoides) and even those with ubiquitous behavior (e.g., Leucanthemopsis alpina, Agrostis rupestris, P. alpina; see Ref. [28]).

Chances for wind-dispersed early colonizers to reach the recently deglaciated glacier forelands are closely linked to the distance to seed sources. Even if taxa can be transported by wind over distances of up to a few kilometers (see Ref. [27]), highest seed rain is within a radius of several meters around the seed source [25, 27]. The longer the transport, the lower the chance to reach the new terrain, as the seeds may ground somewhere else or the diaspores are completely lost when carried to unsuitable sites for germination (water bodies, rocks, snow, dense established vegetation, etc.). The differences in species numbers, individual numbers, and ground cover values between the two study areas can be partly explained by differences in diaspore supply. Lenksteinferner is exposed to the North at a relatively high elevation (>2600 m a.s.1.) and surrounded by sparsely vegetated scree slopes with poor diaspore supply. More abundant seed sources are to be found at lower elevations from where seeds have to be carried up by valley winds. For instance, in 2015, a small larch seedling (Larix decidua) was encountered 300 vertical meters and more than $1 \mathrm{~km}$ away from the last conebearing adult Larch tree. Whether this seedling will survive remains to be seen; still, it highlights the relevance of long-distance dispersal for early colonization in glacier forelands. That Lenksteinferner is lagging behind Goldbergkees concerning species and individual numbers as well as groundcover values (Figure 3) most likely results from the larger distance to potential seed sources and thus the higher risk of diaspores getting lost. At Goldbergkees, located on lower elevation and in a more favorable exposure, last patches of closed alpine vegetation in the surrounding serve as seed sources for the colonization of the glacier foreland and are responsible for the higher species and individual numbers there. Besides wind, also water, avalanches, or mudflows might be locally important dispersal vectors for seeds or even whole plants into glacier forelands [26]. In addition, primary succession in glacier forelands might also be affected by seeds and plants originating from (debris-covered) glacier surfaces that are deposited in the glacier foreland after ice-melt [29-31].

\subsection{Step 2 in primary succession: establishing}

The second important step of primary succession in glacier forelands is a successful establishment of plants. This is not guaranteed for all diaspores that reach the glacier foreland, and there are high interspecific differences in seedling recruitment and survival [26, 32-34]. A study [32] has shown that in some species chances for germination are highest within the first year but declining shortly thereafter. For Artemisia genipi and Achillea moschata, germination success within the first year was at $98.8 \%$ and $68.8 \%$, respectively. For other species, e.g., Linaria alpina or S. oppositifolia, germination success within the first year was very low $(0.4 \%$ and $2.0 \%$, respectively) but much higher during the following years. Such taxa build up a seed bank waiting for the right conditions to sprout, with diaspore morphology and diaspore weight determining how long the seeds are able to survive. A higher weight and a more compact seed coat increase the chance for successful germination after some years of dormancy. Those differences in germination behavior are reflected by the species frequencies 
in the glacier forelands studied. Species which are able to sprout immediately after reaching the glacier foreland show a swift increase in individual numbers and ground cover (e.g., O. digyna, G. reptans, C. uniflorum, A. alpina), while others with low germination success without interim dormancy such as L. alpina are significantly underrepresented [17].

Once diaspores have germinated, the next obstacle is to survive the juvenile stage, which is a particularly sensitive phase and characterized by high mortality rates due to different potential threats $[3,5,26,35]$, which should be discussed next. Despite low contents of organic material, nitrogen, and phosphor, nutrient matter does not seem to be responsible for seedling mortality in glacier forelands. Just after ice retreat, the substrate has sufficient nutrients by atmospheric dust and N-depositions to instantly allow plant growth [28, 36-39]. Algae, cryptogams, and mosses might be involved but obviously do not play an important role in site melioration [17, 21, 40]. More important for the establishment of diaspores than nutrient matters are probably the prevailing substrate conditions. Glacier forelands are commonly regarded as unconsolidated, instable ground with a high amount of coarse rocks impeding colonization by plants. The permanent plots on Goldbergkees and Lenksteinferner locally feature a high amount of coarse material, but situated on more or less leveled ground this is remarkably solid [17]. Soil frost activity (solifluction, cryoturbation) is effectively suppressed by a long-lasting snow cover for 8-9 month and only rare freezing events during the snow-free season (late June/early July to late September/ early October). Thus substrate instability cannot be assumed a universal factor for seedling mortality in alpine glacier forelands. Also, a high amount of coarse boulders is no obstacle for colonization, a minimum of fine grained substrate provided for rooting and water supply. In fact, larger rocks provide safe sites with microclimatically more favorable conditions (shorter snow cover duration, pronounced warming, etc.), and a lack of such safe sites significantly enhances seedling mortality and slows down early colonization within glacier forelands [11]. Despite a high amount of precipitation, reduced evapotranspiration, and additional water supply by melting snow and ice, desiccation of the coarse-grained substrates could be another important reason for mortality in glacier forelands, in particular during seedling and early development stage [4, 41,42]. In particular under longerlasting drought phases and/or reduced snow cover related to climate warming, desiccation might become a more important issue in the future. Concerning soil temperatures multiyear measurements in the root horizon of plants $(-10 \mathrm{~cm})$ show rather mild conditions within glacier forelands [17]. Despite high inter- and intra-annual variations ( 50\%) which are expressed primarily in the length of vegetation period and temperature sums, mean temperatures between 6 and $10^{\circ} \mathrm{C}$ were recorded during the snow-free period in the glacier forelands of Lenksteinferner and Goldbergkees. These are higher temperatures than at tree line, where the trees make themselves a cold root horizon by shadowing effects [43]. Freezing temperatures within the root horizon in the glacier forelands occur but are rare during the snow-free season. While seeds are rather unsusceptible to moderate freezing, seedlings are not [6]. Species investing primarily in aboveground biomass are particularly at risk, while those that invest mainly in below-ground biomass during the first year (e.g., O. digyna) are less vulnerable, show lower mortality rates, and are represented by higher individual numbers and ground cover values [17, 25]. Besides desiccation and freezing during the vegetation period, the winter months are the second crucial phase for the survival 
of seedlings. A snow cover lasting for too long can prevent successful establishment and carbon gain; if snow cover removal is too early, the risk of freezing damage to the seedlings is high, and in addition, periglacial processes may mechanically negatively affect the roots. In the glacier forelands of Goldbergkees and Lenksteinferner, seedling mortality in general is low, indicating that none of the mentioned potential threats is common or at least was common during the study period between 2005 and 2015.

\subsection{Step 3 in primary succession: grow up and spread}

The third important step for a successful plant colonization of new ground is grow up and spread [18]. Many of the early colonizers are long-lived taxa, with a life expectancy of up to 50 years, in clonal and cushion plants even more [42]. Once established, plants occupy their sites for decades [44, 45], unless the site conditions change fundamentally. With water and nutrient supply ensured, established plants grow and gain ground cover under almost uncompetitive conditions. Like all perennial plants, also the high-elevation specialist alternates between phases of growth and phases of reproduction, which are subject to seasonal cycles [46]. Day length and/or a priori low-temperature period during winter ("vernalization") control the right timing of flowering. While after the cold stimulus and during early summer investment is mainly in reproductive plant parts, after fruiting biomass increase is again paramount (see Ref. [47] for A. alpina). Simultaneously with growth new individuals establish from both external seed sources and diaspore-bearing individuals on the sample sites itself. A synchronous operation of steps 1, 2, and 3 side by side is pushing forward succession. In consequence, a positive logarithmic or even exponential increase of species numbers, individual numbers, and ground coverage emerges as soon as the established individuals produce diaspores, which commonly happens the second year after establishment [25]. As most seeds are deposited in the immediate surrounding of the mother plant (leptokurtic diaspore dispersal behavior!), this direct diaspore input is superior to long-distance dispersal [5, 25, 27]. In addition, the ability for self-pollination in many taxa enhances the reproductive success, albeit at the expense of genetic variability.

Besides seed rain also vegetative propagation of capable species is relevant for increasing ground cover values and individual numbers of established plants [42, 45]. One of those species that perform both generative and vegetative propagations is the stolon-producing G. reptans (see Figure 4). The downside of reduced genetic variability is compensated by spread even in unfavorable years prohibiting generative propagation [48]. Another way of vegetative (clonal) reproduction is performed by P. alpina (Figure 4) which is producing bulbils in its pseudo-viviparous form. The development of genetically identical daughter plants instead of seeds is triggered by unfavorable site conditions and thus becomes more important under adverse conditions with higher elevation [42]. In the glacier forelands, the pseudo-viviparous form is much more common than the normal seed-producing form. The daughter plants are photosynthetically active already on the mother plant and after release are dispersed by wind. In doing so, a faster and more successful establishment within the glacier forelands is guaranteed compared to the development of diaspores with all the uncertainties during establishment. In preserving the genetic information, this strategy could even be a selective advantage for P. alpina in comparison to the non-viviparous form [49]. 
The permanent plot studies show a very dynamic colonization of recently deglaciated ground. Vegetation dynamics in general are governed by the relative favor or disfavor of a site, which is a function of many different interrelated factors such as elevation, exposure, snow cover duration, continentality, existence of safe sites, seed sources, etc. Despite differences in the absolute values, in general, a swift fill-up of empty niches is taking place during the first decade of the permanent plot study, promoted by the growth of established individuals as well as by a continuous colonization by new individuals. These are invasive populations according to Ref. [50] with young individuals prevailing. A more uniform ("Gaussian") distribution with many species of intermediate age and few young and old ones, which would indicate stable populations (see Ref. [45]), is not yet reached. Several species invest most of the resources in generative reproduction and are able to create persistent diaspore banks. Many of the early colonizers also show ruderal characteristics [51] such as fast increment, the ability for self-pollination, or anemochorous dispersal. Just like their lowland counterparts, alpine ruderals are able to colonize sites with a high disturbance frequency, unlike, however, is their much greater life expectancy $[42,45]$. Most of the species encountered in the sample sites are far from their maximum age, explaining the low number of losses in the repeated surveys. If dropouts occur, they are compensated by newly established individuals of the same species, expressed in a general increase of groundcover and individual numbers. One notable exception is A. alpina with a life expectancy of only a couple of years. In both glacier forelands, this species is regularly present with diebacks during resurveys. A. alpina, however, as self-pollinating species [47] produces a high number of diaspores able for immediate germination and thus a high number of seedlings every year. The short life cycles of $A$. alpina causing a continuous dieback of individuals keep increase of individual numbers moderate compared to more long-lived species such as O. digyna, C. uniflorum, or S. bryoides. Only locally temporary setbacks in the overall vegetation development by disturbances are apparent [17]. Most common is the displacement of meltwater runoff over-pouring the sample sites for a while. The overdose of (cold) water, probably combined with a higher frequency and intensity periglacial processes in the substrate (solifluction, cryoturbation, needle ice, etc.) negatively impacts the life processes of the plants, which is expressed in diebacks of quite a number of individuals of different species in such cases. When the melt-out stops or the runoff is displaced again, progressive developments reemerge.

\section{Long-term vegetation development in glacier forelands as indicated by chronosequences}

To evaluate vegetation dynamics in glacier forelands on a temporally larger scale, chronosequences are commonly employed. Despite some shortcomings (see above) chronosequences are helpful to hypothesize about long-term vegetation development and offer a good baseline to be corroborated or dismissed by long-running permanent plot studies. Figure 5 exemplifies gradual vegetation changes with time for the chronosequence in the glacier foreland of Goldbergkees. Based on the floristic composition and structural attributes, different successional stages can be identified for both chronosequences surveyed: a pioneer stage, an early 

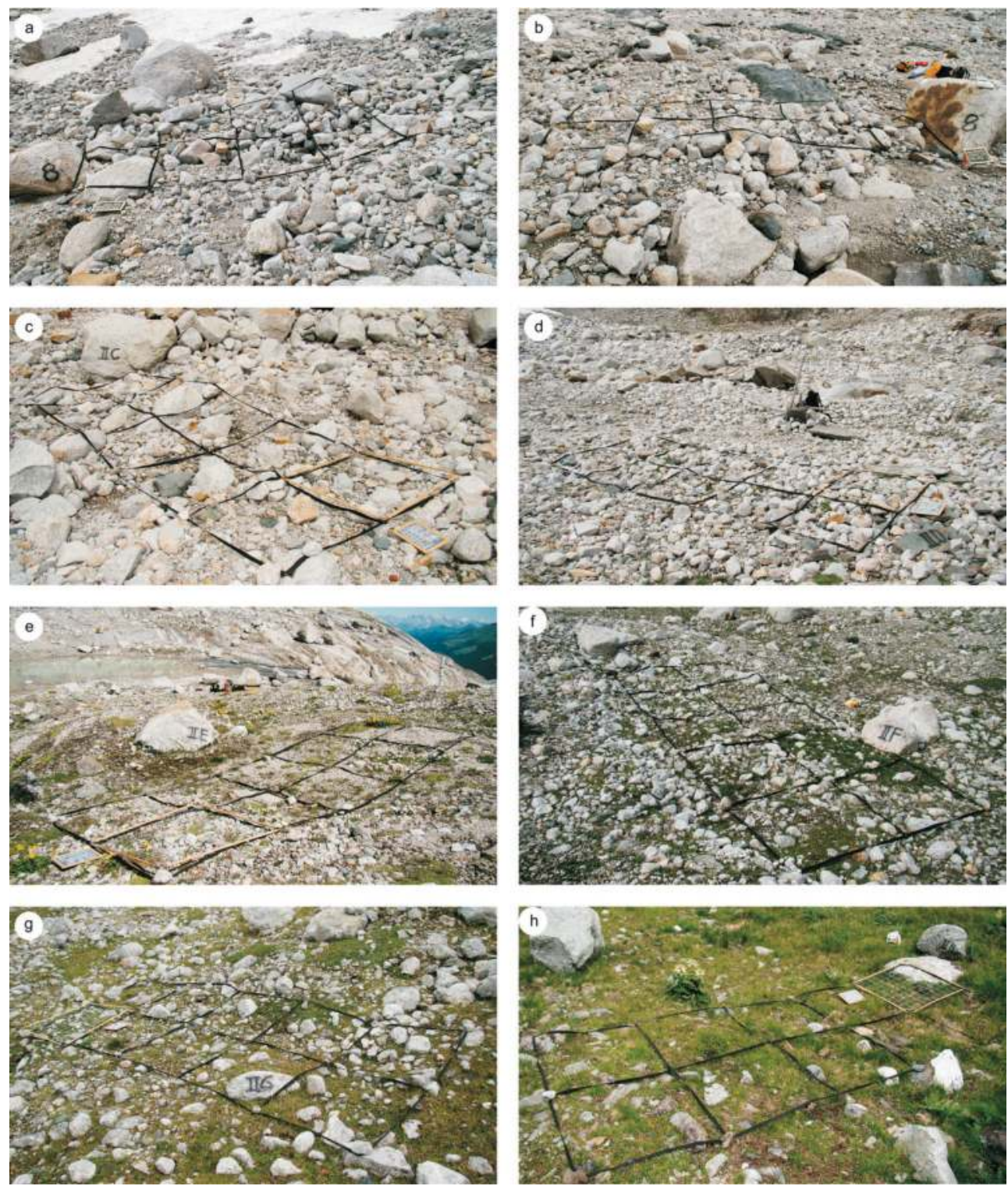

Figure 5. Aspects of sample sites along the chronosequence in the glacier foreland of Goldbergkees (the central site out of three per level) illustrate the gradual vegetation change with time. Time since melt-out is 2 years (a), 4 years (b), 15 years (c), 25-30 years (d), 55 years (e), 85 years (f), 120 years (g), and 155 years (h).

successional stage and a later successional stage, which might be further subdivided in a grass-dwarf shrub-phase and a shrub phase. A superordinate species pool characteristic for the siliceous Eastern Alps causes a general similarity between glacier forelands of the Central Eastern Alps (and also for the two presented here); however, the "floristic character 
of the surroundings" [19] depending on local site conditions (elevation, exposure, topography, etc.) is responsible for some discreetness [17].

The PCAs in Figure 6 portray the floristic similarity between samples (the closer located within the ordination space, the higher the similarity) as well as changes in groundcover and life form composition during succession for the two chronosequence studies. The pioneer stage includes sites deglaciated for up to 20 years (A- to C-sites on Goldbergkees, B-sites on Lenksteinferner, A-sites on Lenksteinferner are missing as those three selected were still devoid of vegetation in 2007; see Figure 6), and vegetation development basically reflects the situation on the permanent plots one decade after deglaciation presented above. Substrate is blocky without any signs of initial soil development. Mineral nutrient supply is guaranteed via sediment input by wind and melting glaciers as well as by dry and wet $\mathrm{N}$-deposition [36-39], creating a first "natural manuring." As already revealed by the permanent plot studies, the chamaephytes C. uniflorum, C. cerastoides, S. bryoides, and A. alpina; herbs such as O. digyna, Sagina saginoides, V. alpina, and Cardamine resedifolia; the grass P. laxa; as well as mosses belong to the early colonizers in both glacier forelands. All of the vascular plants are anemochorous species carried to the glacier foreland by valley winds from the surroundings, where they are able to establish without interspecific competition. Within the first two decades, 20-30 different taxa appear on the new ground. Which species accompany the mentioned early colonizers depends on the seed sources in the surrounding and the local site conditions. In general, the pioneer stage is characterized by a high degree of randomness. Ground cover is low with $<2 \%$ on the sites sampled. The early successional stage encompasses sites between 20 and 60 years of age (D- and E-sites on Goldbergkees, C- and D-sites on Lenksteinferner; see Figure 6). Some species already sparsely present within the pioneer stage gain importance (e.g., L. alpina, G. reptans, Gnaphalium supinum, as well as the grasses A. rupestris and P. alpina, again predominantly in the viviparous form), and many additional species join the sites. In total, 30 different species of vascular plants were recorded for the early successional stage on Goldbergkees and 31 on Lenksteinferner. Ground cover increases to values around $10 \%$ on sites deglaciated for roughly half a century, and dwarf shrubs are the predominant life form (Figure 6). Most of the early colonizers are still present with high frequency and/or abundance; on sites older than half a century; however, a continuous influx of additional species segregates the later successional stage (F- to H-sites on Goldbergkees, F- to J-sites on Lenksteinferner) and induces a generally higher dissimilarity between sites than earlier stages (Figure 6). One very common species is Euphrasia minima, one of the few therophytes involved in primary succession in alpine glacier forelands. Species numbers increase to well over 40, and mean ground cover is around $60 \%$. Increasing ground cover and species richness intensify competition and eliminate some pioneers weak in competition. The later successional stage can be further divided into a grass-dwarf shrub phase (present on Goldbergkees) and a shrub phase (present on Lenksteinferner). In the former, the carpetlike dwarf willows Salix herbacea and Salix retusa are very common. The shrub phase is characterized by a higher groundcover of more upright-growing shrubs such as Rhododendron ferrugineum and different willow species (on Lenksteinferner Salix appendiculata and Salix breviserrata). In addition, about 120-150 years after deglaciation, the first conifer taxa such as Juniperus communis ssp. nana, L. decidua, or Picea abies are present in the sample sites on Lenksteinferner (Figure 6). 

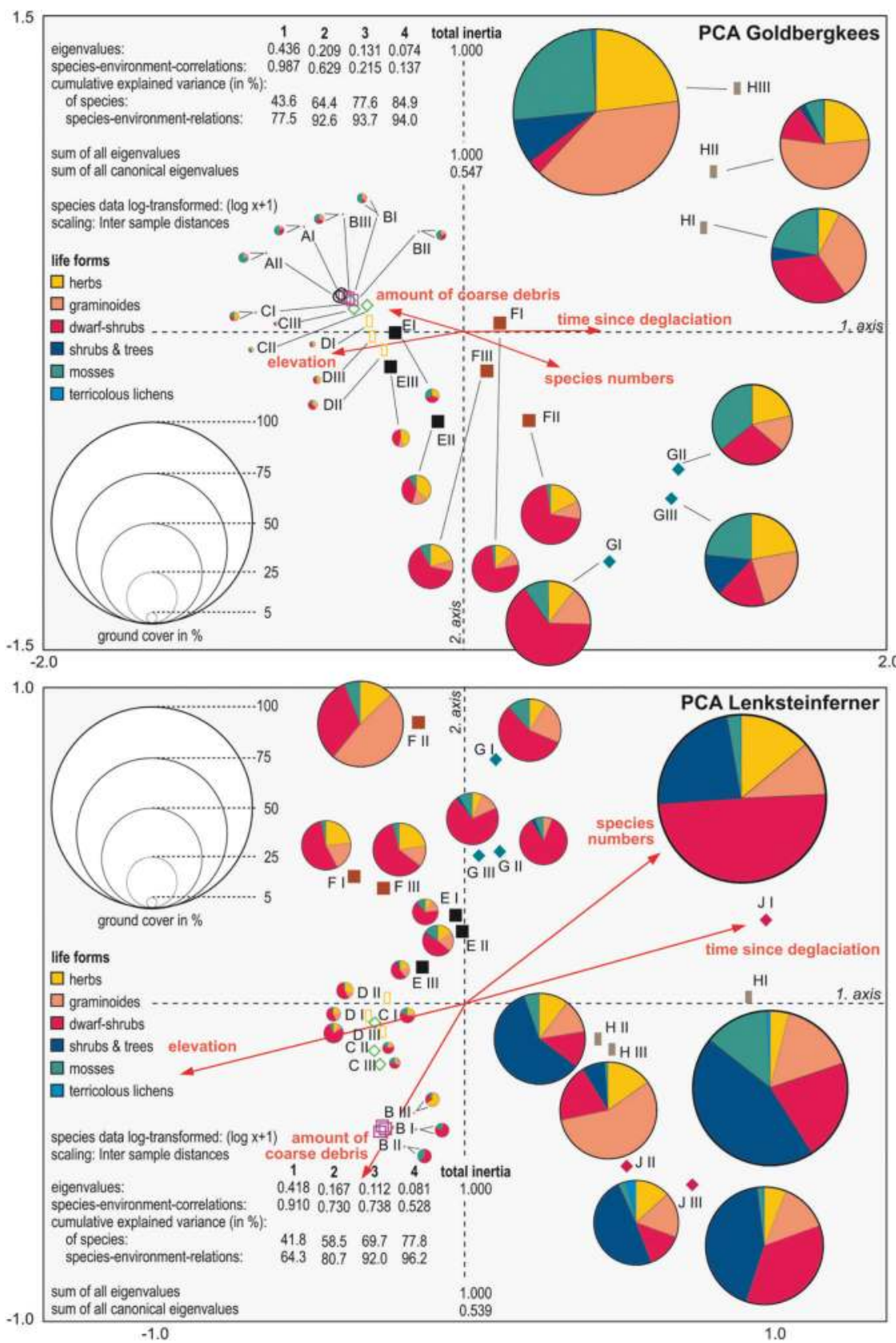

Figure 6. Principal component analyses (PCAs) based on species data for the chronosequence studies in the glacier forelands of Goldbergkees (above) and Lenksteinferner (below). The pies indicate life form composition and total ground cover for all samples. Where necessary (A, B, and C on Goldbergkees, B on Lenksteinferner) pies are zoomed for better reading. 
Succession on new ground is commonly reflected by an increase of species numbers and ground cover, at least until a certain point [52] (see Figure 6). Species diversity of a particular successional stage is not so much triggered by elevation, rather by the vegetation belt in which it is located. For instance, on Goldbergkees sites being deglaciated for one and a half century are located within the alpine belt and exhibit less species than the same-aged sites on Lenksteinferner which are-despite higher absolute elevation-located close to the treeline ecotone allowing for an association of subnival, alpine, and subalpine elements. While the increase of species numbers shows a more negative logarithmic behavior, the development of ground cover is positive logarithmic, i.e., despite a swift increase of species numbers during the pioneer and early successional stages, ground cover values lag behind during the first decades (see Figure 7) - a pattern already observable during the first decade of the permanent plot study. Approximately half a century after deglaciation, a speedup in ground cover becomes apparent. This increase is not always continuous; rather disturbances such as mudflows, relocation of glacial runoff, avalanches, etc. can throw back succession to an earlier stage, as displayed by the decrease in both species numbers and ground cover values on the 90-year-old G-sites on Lenksteinferner (see Figure 7).

Primary succession in glacier forelands is a process that always occurred when glaciers receded, whether in postglacial times, after the LIA, or today with recent climate warming. While the general processes of primary succession were basically always the same, the circumstances controlling these processes may differ between today and the past. Recent studies, at least, found primary succession within glacier forelands of the Alps to be accelerated,

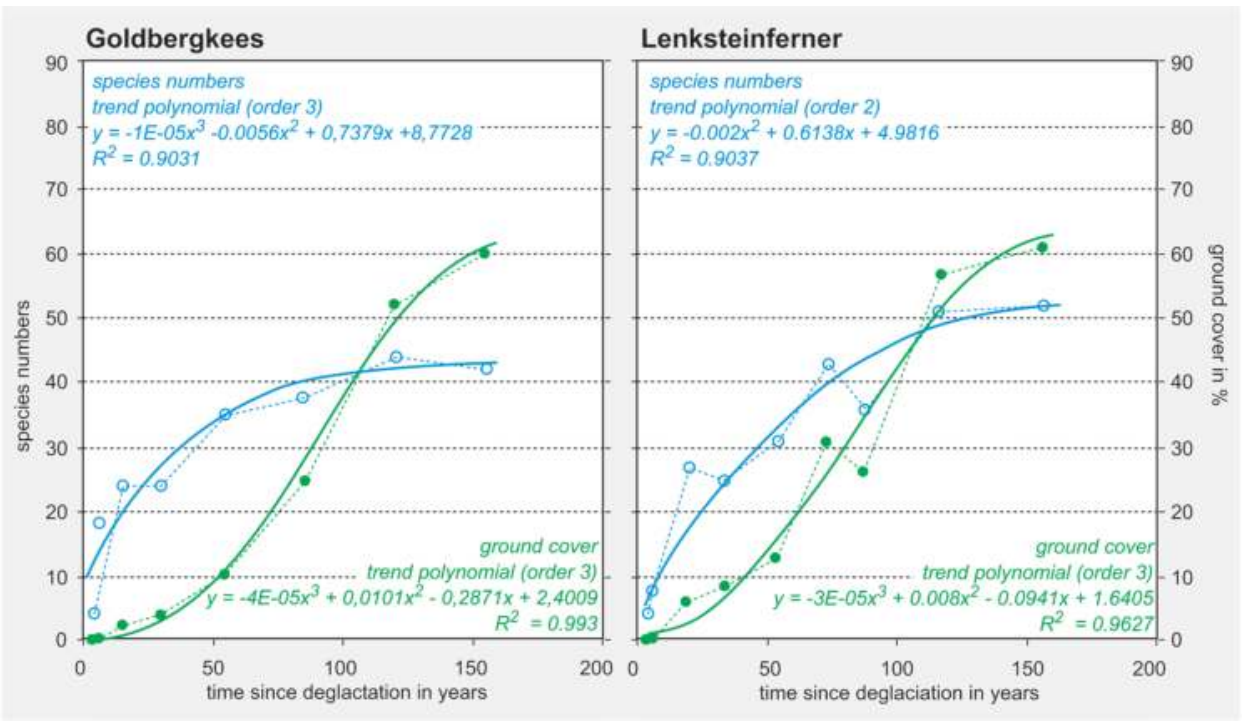

Figure 7. Development (mean out of three samples) of species numbers (blue open circles) and ground cover (green closed circles) along the chronosequences in the glacier forelands of Goldbergkees (left) and Lenksteinferner (right). 
most likely due to climate warming (e.g., Refs. [24, 53]). As a complete list of species present in the foreland of Lenksteinferner was already published for the early twentieth century [19], this glacier foreland offers the great opportunity to compare these historic data with those collected roughly one century later (i.e., those presented here). Ref. [54] employed these two spatiotemporally different data sets to address the question whether primary succession of plants in glacier forelands today differs from the past concerning the dynamics of colonization, the plant species involved, and their respective biological traits. The main outcome of this study was that even if additional species occur and the colonization apparently is faster today compared to the past, fundamental differences concerning the floristic inventory, the biological traits, or the colonization strategies of the early colonizers due to climate change do not exist. This is apparently a consequence of a compensation of climate warming during the twentieth century by the shift of the glacier terminus to a higher elevation. The vertical shift of the glacier snout of Lenksteinferner between the early twentieth and early twenty-first century amounts approximately $300 \mathrm{~m}$ in elevation. Assuming a mean adiabatic temperature lapse rate of $-0.57 \mathrm{~K} / 100 \mathrm{~m}$, mean annual temperatures between the two elevational levels differ by $1.7 \mathrm{~K}$ [54]. This value corresponds quiet well to the magnitude of climate warming between the two sampling dates, and therefore, almost identical thermal conditions can be assumed for the recent glacier foreland (at higher elevation but affected by climate warming) and the one at the beginning of the last century (at lower elevations but under colder climate). As a shift in elevation of glacier termini during recession is a common issue, such compensation effects can be assumed to be a widespread determinant for succession in glacier forelands of the Alps (and elsewhere). Glaciers which terminate in flat glacial valleys (e.g., Morteratsch glacier in the Swiss Engadine [53]) may react differently, as compensation effects of elevation change by climate warming are lacking and the increasing temperatures may immediately affect plant colonization and vegetation dynamics in glacier forelands, allowing thermophilous species of lower elevations to participate in primary succession.

\section{Conclusion}

Studies on plant succession are highly important tasks, not only for the general understanding of the colonization on newly created surfaces but also for providing insight for rehabilitation measures on disturbed ecosystems in general. The combined use of permanent plots and chronosequences interrelates the benefits of the two different approaches while reducing the respective drawbacks. Thus, cautious interpretation allows for the deduction of trends in vegetation dynamics on larger time scales. The permanent plot studies reveal a highly dynamic vegetation development in recently deglaciated glacier forelands with the first plant individuals appearing soon after deglaciation. A surprising fact is how swift the increase of species and individual numbers within the first decade after deglaciation is taking place, and it seems that mutualistic effects are important, while competition does not play a major role at present. Inter- and intraspecific competition becomes more effective later on during succession and in particular becomes apparent one century or more after deglaciation with the dropout of several early colonizers. The high persistency documents that not only pioneer species are involved in colonization of bare ground but early and 
late-successional taxa as well. Even if conclusions of chronosequence studies have to be drawn carefully as other factors than site age might be similarly responsible for the vegetation development encountered, they allow hypothesizing about the future development of recently deglaciated glacier forelands. Whether the trends deduced by chronosequences on the permanent plots in fact appear remains to be seen when the long-term monitoring will be continued over the next decades.

\section{Author details}

Thomas Fickert

Address all correspondence to: thomas.fickert@uni-passau.de

Physical Geography, University of Passau, Passau, Germany

\section{References}

[1] Ellenberg H. Vegetation Ecology of Central Europe. Cambridge: Cambridge University Press; 1988. p. 731

[2] Pickett STA. Space-for-time substitution as an alternative to long-term studies. In: Likens GE, editor. Long-term Studies in Ecology: Approaches and Alternatives. New York: Springer; 1989. pp. 110-135

[3] Matthews JA. The Ecology of Recently-deglaciated Terrain. A Geoecological Approach to Glacier Forelands and Primary Succession. Cambridge: Cambridge University Press; 1992. p. 386

[4] Innes JL. Lichenometry. Progress in Physical Geography. 1985;9:187-254

[5] Jones CC, del Moral R. Dispersal and establishment both limit colonization during primary succession on a glacier foreland. Plant Ecology. 2009;204/2:217-230

[6] Marcante S, Sierra-Almeida A, Spindelböck JP, Erschbamer B, Neuner G. Frost as a limiting factor for recruitment and establishment of early development stages in an alpine glacier foreland? Journal of Vegetation Science. 2012;23/5:858-868

[7] Connell JH, Slatyer RO. Mechanisms of succession in natural communities and their role in community stability and organization. The American Naturalist. 1977;111/982:1119-1144

[8] Olofsson J, Moen J-L, Oksanen L. On the balance between positive and negative plant interactions in harsh environments. Oikos. 1999;86:539-543

[9] Callaway RM, Brooker RW, Choler P, Kikvidze Z, Lortiek CJ, Michalet R, Paolini L, Pugnaireq FI, Newingham B, Aschehoug ET, Armasq C, Kikodze D, Cook BJ. Positive interactions among alpine plants increase with stress. Nature. 2002;417:844-848 
[10] Dullinger S, Kleinbauer I, Pauli H, Gottfried M, Brooker R, Nagy L, Theurillat J-P, Holten JI, Abdaladze O, Benito J-L, Borel J-L, Coldea G, Ghosn D, Kanka R, Merzouki A, Klettner C, Moiseev P, Molau U, Reiter K, Rossi G, Stanisci A, Tomaselli M, Unterlugauer P, Vittoz P, Grabherr G. Weak and variable relationships between environmental severity and small-scale co-occurrence in alpine plant communities. Journal of Ecology. 2007;95:1284-1295

[11] Erschbamer B, Niederfriniger Schlag R, Winkler E. Colonization processes on a central alpine glacier foreland. Journal of Vegetation Science. 2008;19/6:855-862

[12] Raunkiaer C. The Life-forms of Plants and Statistical Plant Geography. Oxford: Oxford University Press; 1934. p. 632

[13] Müller-Schneider P. Verbreitungsbiologie der Blütenpflanzen Graubündens. Zürich: Veröffentlichungen des Geobotanischen Instituts der Eidg. Techn. Hochschule, Stiftung Rübel, 85; 1986. p. 263

[14] Fischer MA, Adler W, Oswald K. Exkursionsflora für Österreich, Liechtenstein und Südtirol. Linz: Land Oberösterreich, Biologiezentrum der OÖ Landesmuseen; 2005. p. 1392

[15] Böhm R, Schöner W, Auer I, Hynek B, Kroisleitner C, Weyss G. Gletscher im Klimawandel - Vom Eis der Polargebiete zum Goldbergkees in den Hohen Tauern. Wien: ZAMG; 2007. p. 111

[16] Damm B. Die Entwicklung der Vergletscherung in der Rieserfernergruppe (Tirol) seit dem Hochstand von 1850. Der Schlern. 1997;71/10:593-618

[17] Fickert Th. Zur Bedeutung von Dauerbeobachtungsstudien in der Sukzessionsforschung-Zwei Fallstudien zur Primärsukzession in Gletschervorfeldern in den Ostalpen und zur Sekundärsukzession sturmgestörter Mangrovenwälder in Honduras. Passauer Schriften zur Geographie H. 29, Passau: Selbstverlag Fach Geographie der Universität Passau; 2016. p. 158

[18] Bradshaw A. Understanding the fundamentals of succession. In: Miles J, Walton DWH, editors. Primary Succession on Land. Oxford, Boston: Blackwell Scientific Publications; 1993. pp. 1-3

[19] von Klebelsberg R. Das Vordringen der Hochgebirgsvegetation in den Tiroler Alpen-Eine alpin-pflanzengeographische Studie. Österreichische Botanische Zeitschrift. 1913;63/5 \& 63/6:77-186 \& 241-254

[20] Lüdi W. Beobachtungen über die Besiedlung von Gletschervorfeldern in den Schweizeralpen. Flora. 1958;146:387-407

[21] Richard JL. Dynamique de la végétation au bord du grand glacier d'Aletsch (Alpes Suisses). In: Schmidt W, editor. Sukzessionsforschung. Berichte der Internationalen Symposien der Internationalen Vereinigung für Vegetationskunde (Rinteln 1973), Cramer, Vaduz; 1975. pp. 189-209 
[22] Burga CA, Krüsi B, Egli M, Wernl M, Elsener S, Ziefl M, Fischer T, Mavrisa M. Plant succession and soil development on the foreland of the Morteratsch glacier (Pontresina, Switzerland): Straight forward or chaotic? Flora. 2010;205:561-576

[23] Zollitsch B. Die Vegetationsentwicklung im Pasterzenvorfeld. Wissenschaftliche Alpenvereinshefte. 1969;21:267-290

[24] Cannone N, Diolaiuti G, Guglielmin M, Smiraglia C. Accelerating climate change impacts on alpine glacier forefield ecosystems in the European Alps. Ecological Applications. 2008;18/3:637-648

[25] Stöcklin J, Bäumler E. Seed rain, seedling establishment and clonal growth strategies on a glacier foreland. Journal of Vegetation Science. 1996;7:45-56

[26] Erschbamer B, Kneringer E, Niederfriniger Schlag R. Seed rain, seed bank, seedling recruitment, and survival of seedlings on a glacier foreland in the Central Alps. Flora. 2001;196/4:304-312

[27] Tackenberg O, Stöcklin J. Wind dispersal of alpine plant species: A comparison with lowland species. Journal of Vegetation Science. 2008;9/1:109-118

[28] Caccianiga M, Luzzaro A, Pierce S, Ceriani RM, Cerabolini B. The functional basis of a primary succession resolved by CSR classification. Oikos. 2006;112:10-20

[29] Becker T, Dierschke H. Primärsukzession im Gletschervorfeld des Obersulzbachkees (Hohe Tauern, Österreich), eine Zeitreihe über fast 150 Jahre. Tuexenia. 2005;25:111-139

[30] Fickert T, Friend D, Grüninger F, Molnia B, Richter M. Did debris-covered glaciers serve as Pleistocene refugia for plants? A new hypothesis derived from observations of recent plant growth on glacier surfaces. Arctic, Antarctic, and Alpine Research. 2007;39/2:245-257

[31] Caccianiga M, Andreis C, Diolaiuti G, D'Agata C, Mihalcea C, Smiraglia C. Alpine debris-covered glacier as habitat for plant life. The Holocene. 2011;21/6:1011-1020

[32] Schwienbacher E, Erschbamer B. Longevity of seeds in a glacier foreland of the Central Alps - A burial experiment. Bulletin of the Geobotanical Institute ETH. 2001;68:63-71

[33] Schwienbacher E, Marcante S, Erschbamer B. Alpine species seed longevity in the soil in relation to seed size and shape-A 5-year burial experiment in the Central Alps. Flora. 2010;205:19-25

[34] Schwienbacher E, Navarro-Cano JA, Neuner G, Erschbamer B. Seed dormancy in alpine species. Flora. 2011;206:845-856

[35] Marcante S, Winkler E, Erschbamer B. Population dynamics along a primary succession gradient: Do alpine species fit into demographic succession theory? Annals of Botany. 2009;103:1129-1143

[36] Haselwandter K, Hofmann A, Holzmann HP, Read DJ. Availability of nitrogen and phosphorus in the nival zone of the Alps. Oecologia. 1983;57:266-269 
[37] Chapin III FS, Walker LR, Fastie CL, Sharman LC. Mechanisms of primary succession following deglaciation at Glacier Bay, Alaska. Ecological Monographs. 1994;64/2:149-175

[38] Heer C, Körner Ch. High elevation pioneer plants are sensitive to mineral nutrient addition. Basic and Applied Ecology. 2002;3:39-47

[39] Hiltbrunner E, Schwikowski M, Körner Ch. Inorganic nitrogen storage in alpine snow pack in the Central Alps (Switzerland). Atmospheric Environment. 2005;39:2249-2259

[40] Nagy L, Grabherr G. The Biology of Alpine Habitats. Oxford: Oxford University Press; 2009. p. 376

[41] Urbanksa CM, Schütz M. Reproduction by seed in alpine plants and revegetation research above timberline. Botanica Helvetica. 1986;96:43-61

[42] Körner Ch. Alpine Plant Life. Berlin, Heidelberg, New York: Springer; 2003. p. 344

[43] Körner Ch. Alpine Treelines. Basel, Heidelberg, New York, Dodrecht, London: Springer; 2012. p. 220

[44] Grabherr G, Gottfried M, Pauli H. Long-term monitoring of mountain peaks in the Alps. In: Burga CA, Kratochwil A, editors. Biomonitoring: General and Applied Aspects on Regional and Global Scales, Tasks for Vegetation Science 35. Dordrecht, NL.: Kluwer; 2001. pp. 153-177

[45] Erschbamer B, Retter V. How long can glacier foreland species live? Flora. 2004;199/6: 500-504

[46] Battey NH. Aspects of seasonality. Journal of Experimental Botany. 2000;51/352:1769-1780

[47] Wang R, Farrona S, Vincent C, Joecker A, Schoof H, Turck F, Alonso-Blanco C, Coupland G, Albani MC. PEP1 regulates perennial flowering in Arabis alpina. Nature. 2009;459:423-427

[48] Weppler T, Stoll P, Stöcklin J. The relative importance of sexual and clonal reproduction for population growth in the long-lived alpine plant Geum reptans. Journal of Ecology. 2006;94:869-879

[49] Pierce S, Stirling CM, Baxter R. Pseudoviviparous reproduction of Poa alpina var. vivipara L. (Poaceae) during long-term exposure to elevated atmospheric $\mathrm{CO}_{2}$. Annals of Botany. 2003;91/6:613-622

[50] Rabotnov TA. Differences between fluctuations and successions. In: Knapp R, editor. Vegetation Dynamics. Handbook of Vegetation Science 8. The Hague: Dr. W. Junk b.v., Publishers; 1974. pp. 19-24

[51] Grime JP. Vegetation classification by reference to strategies. Nature. 1974;250:26-31

[52] Andreis C, Caccianiga M, Cerabolini B. Vegetation and environmental factors during primary succession on glacier forelands. Plant Biosystems. 2001;135/3:295-310 
[53] Burga CA. More and quicker new land for pioneer plants and faster plant settlement-14 years plant monitoring of the glacier foreland Morteratsch (2000 m a.s.l., Pontresina, Upper Engadine, Switzerland). In: Frei ER, Stöckli V, Rixen C, Wipf S, editors. Faster, Higher, More? Past, Present and Future Dynamics of Alpine and Arctic Flora under Climate Change. Abstracts. Intern. Conference; September 22-25, 2013; Bergün, Switzerland. Birmensdorf: Swiss Federal Institute for Forest, Snow and Landscape Research WSL; 2013

[54] Fickert T, Grüninger F, Damm B. Klebelsberg revisited: Did primary succession of plants in glacier forelands a century ago differ from today? Alpine Botany. 2017;127:17-29. DOI: 10.1007/s00035-016-0179-1 